\title{
TOXICOLOGICAL AND BEHAVIOR ANALYSES OF A FOLIOSE LICHEN PARMOTREMA TINCTORUM (DELISE EX NYL.) HALE EXTRACT USING ZEBRAFISH (DANIO RERIO) MODEL
}

\section{MUTHU SHENBAGAM ${ }^{1}$, MURUGAN MARIRAJ ${ }^{1}$, RAJENDRAN KALIDOSS ${ }^{2}$, MACHAMPALAYAM ARUMUGAM DEEPA $^{3}$, PONNUSAMY PONMURUGAN ${ }^{1 *}$}

${ }^{1}$ Biomedical Research Laboratory, Department of Botany, Bharathiar University, Coimbatore, Tamil Nadu, India. ${ }^{2}$ Department of Biotechnology, Sri Kaliswari College, Sivakasi, Tamil Nadu, India. ${ }^{3}$ Department of Botany, Government Arts College, Coimbatore, Tamil Nadu, India. Email: drponmurugan@gmail.com

Received: 20 May 2021, Revised and Accepted: 10 September 2021

ABSTRACT

Objective: The objective of the study was to evaluate the toxicity and behavior analysis with the extract of foliose lichen Parmotrema tinctorum against the adult zebrafish.

Methods: The zebrafishes were exposed to different concentrations of $P$. tinctorum extract such as 50, 100, and 200 mg/ml for 7 days of exposure, in which the mortality and behavioral responses of zebrafishes were recorded. The standard histopathological examination was conducted with the lichen extracts of P. tinctorum.

Results: The results revealed that $P$. tinctorum extract did not show any prominent behavior abnormalities in zebrafishes even at a high concentration of $200 \mathrm{mg} / \mathrm{ml}$. The extract was found to have dose-dependent toxic to zebrafish and the number of neutrophil cells in the muscle bundles reduced at a high concentration. The results of the inflammatory marker gene expression using polymerase chain reaction results suggested that the dosedependent suppression of tumor necrosis factor gene by the P. tinctorum lichen extract.

Conclusion: Overall, concluded that the extract might contain anti-inflammatory induction properties and further tests are required to prove apoptosis and anticancer activity using other in vivo or in vitro techniques.

Keywords: Lichen, Parmotrema tinctorum, Zebrafish, Toxicity, Nutraceutical effect, Histopathology, Inflammatory markers.

(C) 2021 The Authors. Published by Innovare Academic Sciences Pvt Ltd. This is an open access article under the CC BY license (http://creativecommons.org/ licenses/by/4.0/) DOI: http://dx.doi.org/10.22159/ajpcr.2021v14i10.42134. Journal homepage: https://innovareacademics.in/journals/index.php/ajpcr

\section{INTRODUCTION}

Parmotrema tinctorum lichen is a rich source of lecanoric acids, orcellinic acids, and atranorin that can be highly active against a vast number of human disorders. The proportion of secondary metabolites, the different solvent extraction procedures, and concentration of the depsides or depsidones have been optimized to be ideal for treating human disorders by our ancient forefathers several 1000 years ago. With the development of drug resistance among the pathogens, the demands for the new drug have also risen in recent years. With physicians targeting the ancient indigenous method of healing the diseases, there has been a need for the discovery of novel drugs. Tamil Nadu, the province of India in Western Ghats, is known for indigenous methodologies of curing diseases using lichen extracts. Despite many species of nutraceutical lichens and their pharmaceutical importance are documented [1-4], a very few species are in use currently. Therefore, lichen exploration is severe in recent years to exploit the biological agent from lichens with nutraceutical values. Anti-inflammatory and toxicological studies of lichen extract are carried out regularly in folk medicine. Crawford to assess the extracts of several lichens might conclude to be nutraceutical [5]. In $20^{\text {th }}$ century, AIDS was the most challenging disease. However, cancer has been one of the most common diseases forever, with the huge annual deaths across the world. The rapid multiplication of many numbers of cells of the body tissues leads to the development of cancer in our body system. The affected person may have signs in the bone, inflammation in the tissues or lymph nodes. Although a number of lichen species extracts which can reveal antiinflammatory roles have been examined, one lichen $P$. tinctorum is the least known. The extracts in such lichen species exhibit the activity of anti-inflammatory ideally. Zebrafish embryo studies can reveal the possession of anti-inflammatory activity in the $P$. tinctorum lichen extracts, but it is only after the gene analysis that such activity can be well identified.

Current safety and toxicology testing methods of different herbal products are being considered as comprising traditional preclinical studies. Potentially, zebrafish is used in in vivo methods to assess the cytotoxic activity of the lichen extracts. This zebrafish model is a less expensive and reliable model to study the toxicological screening [6]. Zebrafish exhibits a high resemblance to human neurobehavioral phenotypes and neurotransmitter systems [7]. The novel test is an open glass aquarium setup which is similar to the open field test for rodent's studies to assess anxiety and behavioral investigations in the zebrafish [8]. In addition, it is a fascinating research model for the toxicological studies of a novel drug to obtain results within a short period without much complications $[9,10]$. The proportion of balanced nutrients and dosage of dietary elements can promote the reproductive and early growth phase of zebrafish which in turn be useful to assess the toxicity and behavior analysis of lichen compounds [11].

The fungi, algae, bacteria, and actinomycetes or two or more partners are associated to form lichens. P. tinctorum (Nyl) Hale is an edible lichen, used in the meat and vegetable preparations by ethnic groups in India and Nepal since ancient times [12]. P. tinctorum is a prominent foliose lichen belonging to Parmeliaceae members which are mostly corticolous (found in tree barks) and saxicolous (found in rocks) in nature. The reason for the selection of lichens P. tinctorum and consequent explorations in their metabolite potentiality in Kodiakanal hills is due to the highly abundant of such species biodiversity set around the area. Honda et al. documented the antimicrobial activity of $P$. tinctorum [13]. The depsides, depsidones produced by the lichen thallus exhibited its biological 
activity. Tiwari et al. confirmed the antifungal activity of methanol extracts of $P$. tinctorum [14]. Anjali et al. examined the antibacterial and antifungal activity of solvent extracts of $P$. tincotrum [15]. Vivek et al. and Poornima et al. reported that the extracts of $P$. tinctorum exhibited the DPPH radical scavenging activity $[16,17]$. Ganesan et al. reasoned the radical scavenging activity of $P$. tinctorum was due to the high phenolic content [18]. Therefore, the lichen compounds of the P. tinctorum can be extracted to treat microbial diseases and for application as antioxidants. Although antimicrobial and antioxidant activities of such genus can be found in the literature, anti-inflammatory properties of this genus have not been assessed extensively [19].

\section{MATERIALS AND METHODS}

\section{Plant material}

Fresh thallus of a foliose lichen, P. tinctorum (Delise ex Nyl.) Hale collected from Kodaikanal hills of the Western Ghats in southern India was used for the present study. The altitude of the hills was $2130 \mathrm{~m}$ above mean sea level, and latitude and longitude of the hills, respectively, were $10^{\circ} 14^{\prime} 17.21^{\prime \prime} \mathrm{N}$ and $77^{\circ} 29^{\prime} 21.06^{\prime \prime} \mathrm{E}$. The lichen specimens were identified based on the lichen identification key of [20]. The samples were characterized by studying their external morphology, reproduction structures, anatomical features, and chemical profile referred from the lichen manual of Culberson and Krishnan (1970). The color test was done on medulla of lichen thallus using test reagents such as potassium hydroxide $(\mathrm{K})$, calcium hydroxide $(\mathrm{C})$, and Paraphenylene diamine (PD) as per the protocol of [21].

\section{Extraction of secondary metabolites from $P$. tinctorum}

Bioactive secondary metabolites were extracted from the powder $(5 \mathrm{~g})$ thallus of P. tinctorum by the Soxhlet methods [22]. The extraction was carried out using $250 \mathrm{ml}$ of methanol and heated up to $80^{\circ} \mathrm{C}$ for $8 \mathrm{~h}$. The crude lichen extracts were concentrated using a rotary vacuum evaporator and stored at $-5^{\circ} \mathrm{C}$ temperature until further use.

\section{Identification of lichen secondary metabolites by thin layer chromatography (TLC)}

Five gram of air-dried lichen samples was blended with $100 \mathrm{ml}$ of acetone at room temperature in a magnetic stirrer. The filtrate was separated through Whatman No. 1 filter paper and evaporated to dryness. TLC was used to identify the bioactive secondary metabolites present in the lichen extract using Toluene: Dioxane: Acetic acid (36:9:1) solvent system containing a TLC glass cabinet. The developed TLC plates were sprayed with sulfuric acid, air-dried, and observed the spots under Ultraviolet light of 253 254 nm [23].

\section{Animals and experimental design}

Adult zebrafishes (Danio rerio, $\mathrm{AB}$ wild type strain) that were healthy and devoid of any malformations or infections were chosen for the study. Before initialization of the experiment, fishes were acclimatized in aquarium glass tanks $(20 \mathrm{~L})$ containing biologically filtered and dechlorinated water at $23 \pm 2^{\circ} \mathrm{C}$ with $10: 14 \mathrm{~h}$ light and dark cycles. In order to mimic the natural habitat of zebrafishes, the tanks were filled with gravel to a height of $2 \mathrm{~cm}$, and a popular aquarium plant (Cabomba aquatica) was submerged. Fishes were fed twice a daily with commercial fish flakes containing protein pellets (Hindustan level limited, Bangalore). Zebrafishes with an average weight of $0.26 \pm 0.03 \mathrm{~g}$ and length of $32 \pm 0.4 \mathrm{~mm}$ were selected. Later, the fishes were removed from the recirculating groups, placed in static groups, and fasted for $24 \mathrm{~h}$ before experimentation. The $\mathrm{pH}$ and dissolved oxygen content of the water was maintained at $6.8-7.3$ and $5.4 \mathrm{mg} / \mathrm{l}$, respectively. Fishes were grouped and separated into various aquarium tanks for the treatment of lichen extracts to check the inflammation if any in the muscle tissues. Zebrafishes were placed in the novel test tank devoid of $P$. tinctorum extract immersion as a drug free system for comparison purposes.

\section{LC $_{50}$ determination of $\boldsymbol{P}$. tinctorum extract using zebrafish}

To obtain the lethal concentration $\left(\mathrm{LC}_{50}\right)$ in terms of acute toxicity of P. tinctorum extract, we followed the guidelines of Organization for
Economic Cooperation and Development for testing the chemicals [24]. The various concentrations of $P$. tinctorum extract from 2 to $10 \mu \mathrm{g} / \mathrm{ml}$ and then from 10 to $50 \mu \mathrm{g} / \mathrm{ml}$ were initially chosen. Finally, 50, 100, and $200 \mu \mathrm{g} / \mathrm{ml}$ dosage of $P$. tinctorum extract was standardized. Immersion administration of $P$. tinctorum lichen extracts was diluted in distilled water as required concentration and the control groups had contact with aquarium water only along with regular feed material. In the control group, seven untreated fishes were maintained in a separate tank. The fishes were not fed for $24 \mathrm{~h}$ before (or) during the experimentation to maintain the constant exposure concentrations. Similarly, the control group was also starved. Fishes from the control as well as treated groups were sacrificed after 7 days of exposure.

\section{Behavior analysis of zebrafish treated with $P$. tinctorum extract} A rectangular aquarium measuring the size of $15 \times 25 \times 20 \mathrm{~cm}$ (width $\times$ length $\times$ height), divided equally into two horizontal sections and demarcated by eight rectangles. The water level was maintained at $18.0 \mathrm{~cm}$ in height, producing a final volume of $6.9 \mathrm{l}$ [25]. A video camera was positioned on the front of the device to capture the exploration of the entire environment. Behavior analysis of treated and untreated fishes in terms of time spent at the top (s), top entries (n), freezing frequency (n), freezing duration (s), and swimming pattern was observed. The observations such as total time spent in upper $2 / 3$ and latency to upper $2 / 3$ entry indicative of anxiogenic state, pattern of movement anxiety like and anti-inflammatory activity of $P$. tinctorum extract were also recorded [26].

Histopathology of muscle tissue of zebrafish treated with P. tinctorum extract

P. tinctorum extract treated and untreated control zebrafishes were anesthetized and decapitated to get their muscle tissues and then fixed in Dietrich's fixative solution $(30 \mathrm{ml}$ ethanol, $1 \mathrm{ml}$ formalin, $2 \mathrm{ml}$ glacial acetic acid and $58 \mathrm{ml}$ of distilled water for $100 \mathrm{ml}$ ). They were washed thrice with a cacodylate buffer at $4^{\circ} \mathrm{C}$ for $10 \mathrm{~min}$ and post-fixed in $1 \%$ osmium tetroxide at $4^{\circ} \mathrm{C}$ for $90 \mathrm{~min}$. They were stained with en bloc staining solution containing $0.5 \%$ uranyl acetate. They were dehydrated with absolute ethanol and the clearing of tissues was done by subjecting to a clearing agent xylene. Finally, they were embedded in melted paraffin wax and sliced to get thin sections with the help of a microtome (Thermo scientific Microm- HM 34 OE). Then the tissue sections were mounted on microscope slides using haematoxylin solution and documented under a light microscope [27].

\section{Extraction of genomic DNA from the muscle tissues of zebrafish}

Around $100 \mathrm{mg}$ of muscle tissues of zebrafish treated with P. tinctorum extract were smashed in a pestle and mortar using liquid nitrogen. The ground tissues were dissolved in $1.2 \mathrm{ml}$ digestion buffer ( $\mathrm{pH} \mathrm{6.4)} \mathrm{and}$ incubated overnight in a water bath at $55^{\circ} \mathrm{C}$. Equal volume of PhenolChloroform-Isoamyl alcohol mixed in the ratio 25:24:1 was added and centrifuged at $3000 \mathrm{rpm}$ for $5 \mathrm{~min}$ at room temperature. The aqueous phase was carefully removed to which $1 / 2$ the volume of $7.5 \mathrm{M}$ ammonium acetate and twice the volume of absolute ethanol were added. They were centrifuged once again at $3000 \mathrm{rpm}$ for $5 \mathrm{~min}$ at room temperature. The pellet containing the genomic DNA of zebrafish was removed carefully and rinsed with $70 \%$ ethanol. The isolated DNA was run on an Agarose gel electrophoresis to separate the DNA fragments $[28,29]$.

Inflammatory marker gene expression through polymerase chain reaction (PCR) due to $P$. tinctorum extract treatments

In order to check any inflammation present in the muscle tissues of zebrafish due to $P$. tinctorum extract treatments, the inflammatory markers such as iNOS (induced Nitric Oxide Synthesis) gene and tumor necrosis factor $(\mathrm{TNF} \alpha)$ and a housekeeping gene, $\beta$-Actin were used. The inflammatory marker and housekeeping genes were designed with NCBI primer BLAST tool search and the specific primers used were given in the (Table 1). The genomic DNA extracted from the mussel tissues of zebrafish along with the specific primers as CDNA was performed using a TAKARA ${ }^{\circledR}$ s EMERALD PCR master mix. The PCR cocktail contained $5 \mu \mathrm{l}$ 
of genomic DNA, $5 \mu \mathrm{l}$ of 25 -fold diluted cDNA template mixed with $2.5 \mu \mathrm{l}$ of each primer and $12.5 \mu \mathrm{l}$ of EMERALD PCR master mix to a final volume of $25 \mu$ l. Amplification of DNA was carried out in 34 cycles using a Thermal cycler (Lark L125, Chennai, India) and the resulting PCR product was resolved in 1\% Agarose gel electrophoresis [30]. The conditions applied for amplification of genomic DNA for inflammatory marker gene expression was given in the (Table 2).

\section{Statistical analysis}

The data generated in the present study were subjected to analyze the mean \pm standard error and one-way analyze of variance.

\section{RESULTS}

\section{$\mathrm{LC}_{50}$ determination of $P$. tinctorum}

The lichen extract was subjected to $\mathrm{LC}_{50}$ analysis in the range of 2, 4, 6, 8 and $10 \mu \mathrm{g} / \mathrm{ml}$ concentrations using adult zebrafish observed for 7 days. The results indicated that there were no mortality and behavioral changes of $P$. tinctorum extract treated zebrafish up to $10 \mu \mathrm{g} / \mathrm{ml}$ concentration. The dosage of $P$. tinctorum extract range was increased to $10,20,30,40$ and $50 \mathrm{mg} / \mathrm{ml}$ observed for 7 days. In all the dosages tested, fishes showed normal behavior and no mortality was observed between 10 and $50 \mu \mathrm{g} / \mathrm{ml}$. The dosage level further increased to 50 , 100 and $200 \mathrm{mg} / \mathrm{ml}$ and kept under treatment for 7 days. The results indicated that there was no evident effect in the entire dosage range up to $200 \mathrm{mg} / \mathrm{ml}$ of $P$. tinctorum extract tested. The test samples did not show any prominent effect and abnormal behavior of zebrafishes throughout the treatment period in acute phase.

\section{Behavioral analysis of zebrafishes}

The behavioral analysis of zebrafish treated with $P$. tinctorum extract was carried out for $5 \mathrm{~min}$ at every $30 \mathrm{~min}$ intervals during the first $4 \mathrm{~h}$ exposure and then $5 \mathrm{~min}$ for every $24 \mathrm{~h}$ until $7^{\text {th }}$ day of exposure. Behavior analysis such as anxiety, swimming patterns, aggression, freezing, and top entry were noted. Anxiety of the fishes was noted as soon as they were drawn into the test tanks. The fishes in the control tank rise from darker region to the light region within $1 \mathrm{~min}$ and $30 \mathrm{~s}$ and the fishes in the P. tinctorum extract treated tank took 1.20-1.40 min to reach the light region (Fig. 1a-f). These observations showed that there was no immediate prominent effect on the behavior analysis of fishes treated with P. tinctorum extract. Swimming patterns of the fishes were observed throughout the course of 7 days exposure and fishes in the entire drug treated tanks showed the same swimming

Table 1: Inflammatory marker genes and specific primer pairs used for amplification of genomic DNA extracted from the muscle tissues of zebrafish treated with Parmotrema tinctorum extract

\begin{tabular}{lll}
\hline $\begin{array}{l}\text { Gene } \\
\text { Name }\end{array}$ & Functions & $\begin{array}{l}\text { Forward and Reverse Primer } \\
\text { Sequences (5'\& 3') }\end{array}$ \\
\hline iNOS & Inflammatory & $\begin{array}{l}\text { Fwd: 5' ACACTTCGAAAAGCAAGATGG 3' } \\
\text { Rev: 5' ACGGGCATCGAAAAGCTGTA 3' }\end{array}$ \\
TNF- $\alpha$ & Inflammatory & $\begin{array}{l}\text { Fwd: 5' TCATTTTGGCTGTGGGCCTT 3' } \\
\text { Rev: 5' GGCGGTTCAAAATCTCACTCAC 3' }\end{array}$ \\
$\beta$-Actin & $\begin{array}{l}\text { Housekeeping } \\
\text { gene }\end{array}$ & $\begin{array}{l}\text { Fwd: 5' CCATCGGCAATGAGCGTTTC3' } \\
\text { Rev: 5' CATCCTGAGTCAATGCGCCA 3' }\end{array}$ \\
\hline Fwd: Forward primer sequence, Rev: Reverse primer sequence
\end{tabular}

Table 2: Conditions applied for amplification of genomic DNA extracted from the muscle tissues of zebrafish treated with Parmotrema tinctorum extract

\begin{tabular}{lll}
\hline PCR cycles & Temperature $\left({ }^{\circ} \mathbf{C}\right)$ & Time \\
\hline Initial denaturation & 95 & $2 \mathrm{~min}$ \\
Denaturation & 95 & $1 \mathrm{~min}$ \\
Annealing chosen & Respective to the primer & $30 \mathrm{~s}$ \\
Extension & 72 & $1 \mathrm{~min}$ \\
Final extension & 72 & $5 \mathrm{~min}$ \\
\hline
\end{tabular}

patterns as the fishes in the control tank. There was no change in the swimming patterns. The fishes were also observed for aggression behavior for 7-day exposure similar to that of untreated control fishes. The results further showed that there were no physical changes such as contraction of the dorsal region or any behavioral changes such as swimming toward or against the other fishes in a peculiar manner. The fishes were also observed freezing throughout 7 days of exposure to P. tinctorum extract.

\section{Histopathology of muscle tissues of zebrafish}

Fig. 2 showed the histopathology of muscle tissues of zebrafishes treated with different concentrations of $P$. tinctorum extract such as 50,100 , and $200 \mathrm{mg} / \mathrm{ml}$. The untreated control zebrafishes showed the normal appearance of nuclei and muscle tissues. In addition, they showed the normal histological structures such as fiber bundles, connective tissues, and arrangement of muscle bundles, whereas P. tinctorum extract treated zebrafishes exhibited the muscle bundles in normal arrangements as dose-dependent manner. There was no damage in neutrophil cells in the muscles of zebrafishes treated even in the high dosage $(200 \mathrm{mg} / \mathrm{ml})$ of $P$. tinctorum extract. The results suggested the presence of an increased number of neutrophil cells.

\section{Inflammatory marker gene expression due to $P$. tinctorum extract} treatment in zebrafishes

The gel images revealed that the test samples evoked a significant suppression of upregulation of TNF $\alpha$ and iNOS genes when compared with that of the untreated control zebrafishes in dose dependent manner. The different doses of $P$. tinctorum extract significantly decreased the expression of TNF $\alpha$ and iNOS genes, in which $60 \mu \mathrm{g} / \mathrm{ml}$ dose had shown a marked increase in the expression of TNF $\alpha$ and iNOS genes and decreased at $100 \mu \mathrm{g} / \mathrm{ml}$. $\beta$-Actin gene was used as a housekeeping gene as an internal loading control for comparison purposes (Fig. 3).

\section{DISCUSSION}

The present study was intended to check the efficacy of nutraceutical and toxicological activities of $P$. tinctorum lichen extracts against the adult zebrafishes. The abnormalities in the behavior pattern of $P$. tinctorum-treated zebrafishes were taken as a characteristic biological activity due to toxicological effect and antidepressant actions. The shallow breathing behavioral pattern of zebrafishes treated with various lichen extracts was observed in the previous literature [31]. This is the major sign for the presence of the defense mechanism of zebrafish in a stressful environment. The solvent extracts of $P$. tinctorum were observed to show a lack of biological activity and therefore the behavior abnormalities proved that lichen extract might not have an effective in vivo anti-inflammatory activity. Chemical analysis of P. tinctorum thallus extract revealed the presence of lecanoric acid in the solvent extract as a major phytochemical compound.

Several studies revealed that zebrafish spent more time in the upper region of the novel aquarium tank due to dwelling behavior [32]. Similarly, zebrafishes tend to have natural state affinity to darker sections in the novel tank which is due to a high degree of thigmotaxis and an inherent property of fishes in the water environment. Benneh et al. [8] conducted on an experiment to check the antidepression activity of Maerua angolensis stem bark extract using a robust zebrafish model. They reported that $M$. angolensis extract showed a promising activity in amelioration of anxiety depression 2 months of age, 3.5-4.0 cm in length and weigh on an average of $650 \mathrm{mg}$.

Discouraged by these results, the histopathological study was conducted by standard methods after the behavioral analysis. The previous study with the other lichen extracts has suggested the possession of the immune system boosting ingredients in the lichen extract. The enhancement of immune system might be due to the presence of cellular level differences in the targeted organ [33]. The results of Harvie and Huttenlocher [34] suggested the presence of neutrophils at the injury or at the site of infection. The results of Matthias et al. and Woodfin et 


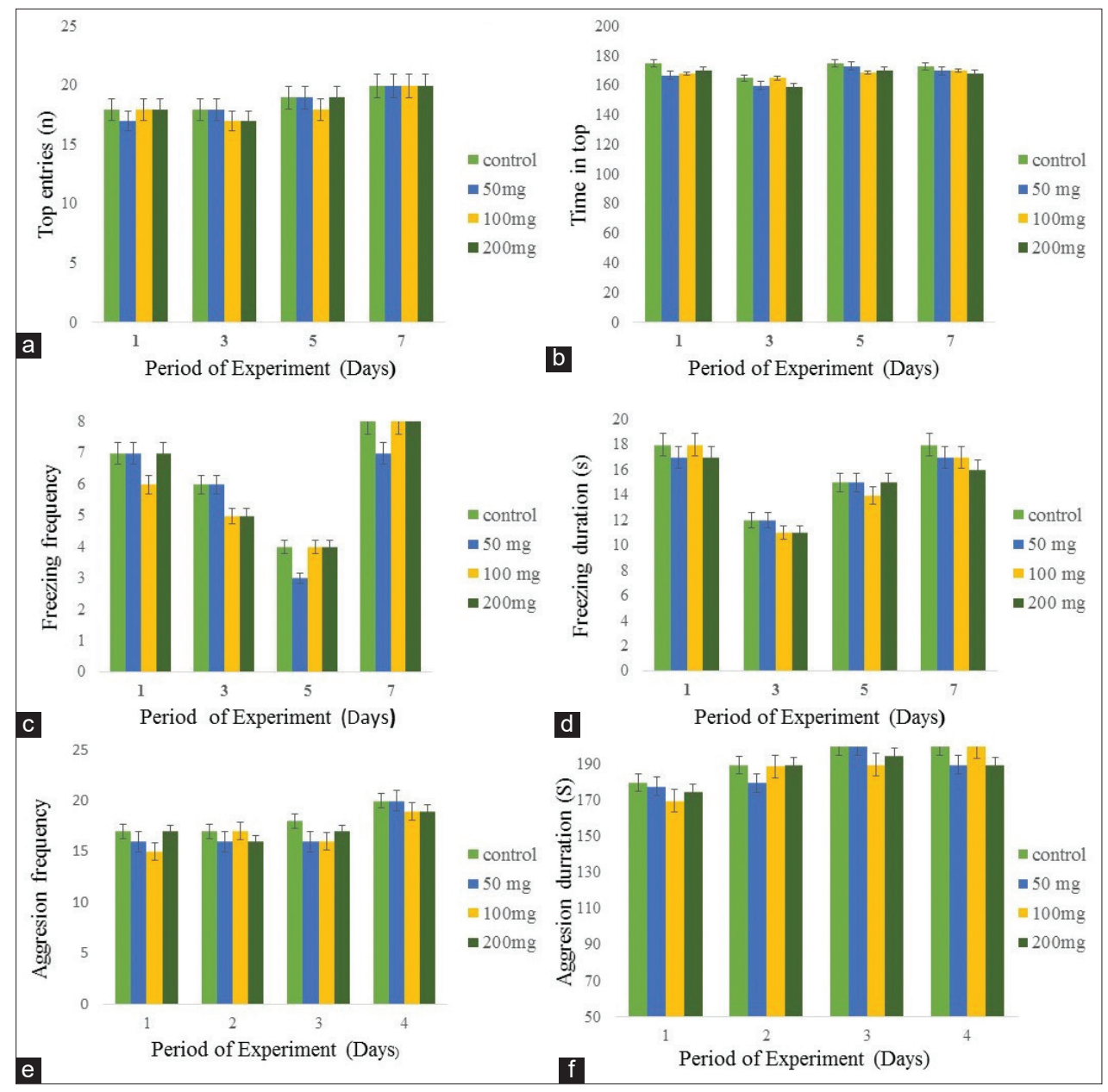

Fig. 1: Behavior analysis of zebrafishes treated with different concentrations of Parmotrema tinctorum extract in the aquarium tank ([a] Top entry by zebrafishes at water level, [b] Time spent to reach at top entry by zebrafishes at water level, [c] Freezing frequency of zebrafishes, [d] Freezing duration of zebrafishes, [e] Aggression frequency of zebrafishes, and [f] Aggression duration of zebrafishes)

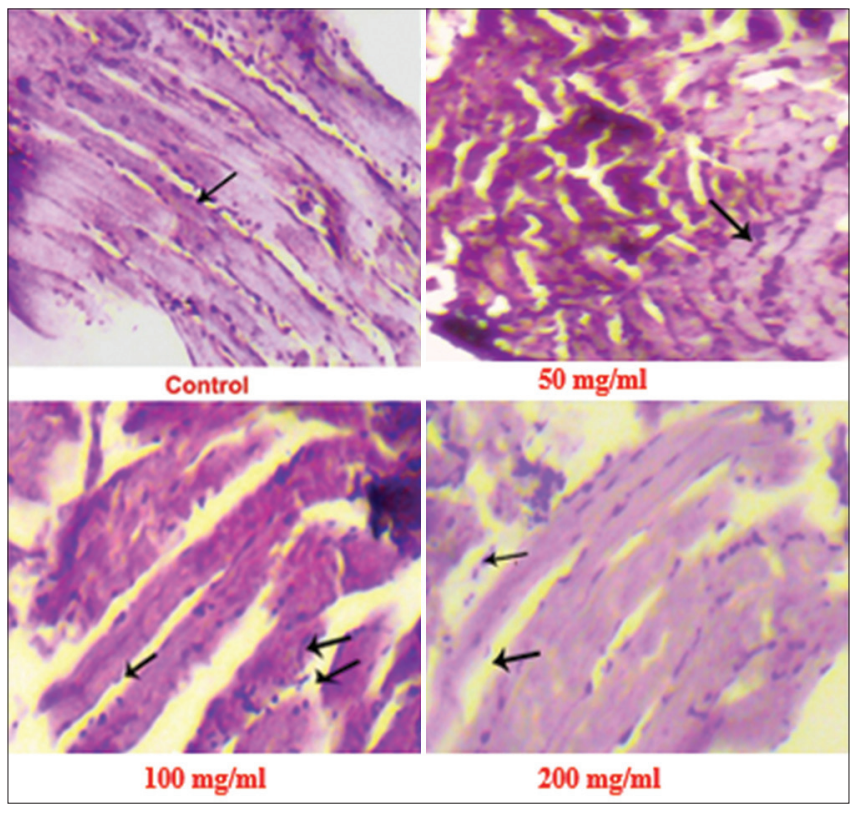

Fig. 2: Histopathological images of muscle tissues of zebrafishes treated with different concentrations of Parmotrema tinctoram extract (The black arrows indicated the neutrophil cells)

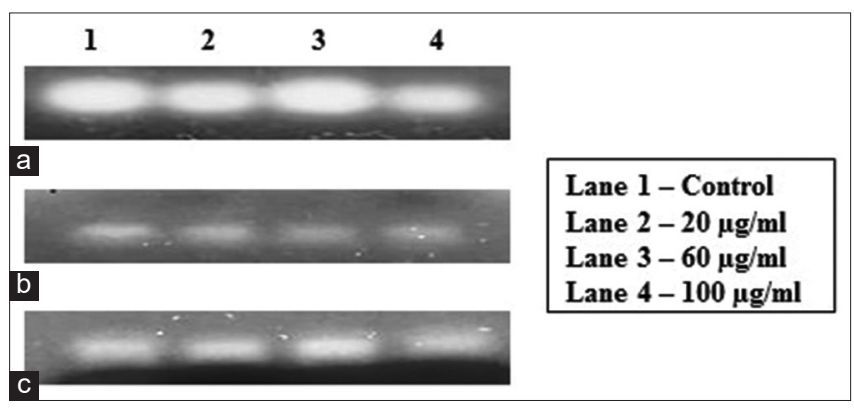

Fig. 3: Inflammatory marker gene expression in zebrafishes treated with different concentrations of Parmotrema tinctorum extract ([a] $\beta$-Actin gene expression, [b] iNOS gene expression and [c] TNF $\alpha$ gene expression)

al. supported the traffic clearance activity of neutrophils at the site of tissue damage by reverse migration process $[35,36]$.

The skeletal muscles in the adult zebrafishes are composed of $60 \%$ body mass and studies on toxic effects of high relevance [37]. Especially, in zebrafish, optical transparency of the larvae could help to elucidate the novel mechanisms of neutrophil behaviour in response to tissue damage and infection. It is said that reversal of neutrophils might serve as a mechanism of systematic action of immune response. Examining 
the changes that appear in muscle tissues of zebrafish which are made of fibers and muscle cells held together by connective tissues would provide factual data regarding tissue damage. In the present work, neutrophil profiling in the mussel tissues of zebrafishes treated with P. tinctorum extract was done (Fig. 2). The cells examined suggested the absence of biological activity in the lichen extract. The results of the histopathological investigation recorded a decreased number of neutrophil cells, suggesting that the lichen extract exhibited anti-inflammatory activity. Hence, the inflammatory marker gene expression due to $P$. tinctorum extract treatment in zebrafish test was carried out, and the results suggested the presence of dose-dependent anti-inflammatory induction activity.

According to Hong et al. [38], usnic acids of Umbilicaria antarctica extract possess dose-dependent survival rate efficiency in zebrafishes. They have demonstrated the presence of decreased survival rate in the $U$. antarctica extract fed zebra fish at a concentration of 200 and $400 \mu \mathrm{g} / \mathrm{mL}$ at 24 and $48 \mathrm{hpf}$. The extract of $P$. tinctorum decreased the gene expression of the tumor necrosis factor, TNF- $\alpha$ which suggested the suppression of cytokine induction (Fig. 3). Since, tumor necrosis factor is found to be present in the suppression of cell proliferation and inflammation, the same was examined using the standard PCR procedure. It was found that the extract had the dose-dependent suppression activity. This is in accordance with the report given by Hong et al. [38] who showed the dose-dependent suppression of TNF- $\alpha$ gene by usnic acid.

\section{CONCLUSION}

A few toxicological researches in the lichen extracts have been conducted extensively. A lichen species, less explored in the Parmotrema genus is $P$. tincotrum. This species is widespread in the study area and biological activities of such species are found in the literature. The lichen compounds of $P$. tinctorum are less studied and were considered to investigate for the present study. Zebrafishes treated with $200 \mathrm{mg} / \mathrm{ml}$ of $P$. tinctorum extract concentration showed an increase in the number of neutrophil cells in the muscle bundles. The supportive studies helped to carry out inflammatory marker gene expression studies through PCR. The results suggested the presence of dose-dependent anti-inflammatory activity in the extract of $P$. tinctorum. Thus, this may be concluded that the $P$. tinctorum extract may be an alternative drug molecule as well as nutraceutical food supplement. Extensive research is required further to acknowledge their anticancer-related biological activities.

\section{ACKNOWLEDGMENTS}

The authors would like to acknowledge Indian Council of Medical Research (ICMR), New Delhi, for financial support to carry out the study. The authors are much indebted to thank Dr. A. Rajendran, Professor and Head, Department of Botany, Bharathiar University, Coimbatore, Tamil $\mathrm{Nadu}$, India, for his critical comments and constant encouragement.

\section{AUTHORS CONTRIBUTIONS}

Ponnuchamy Ponmurugan performed the study design, Muthu Shenbagam, Murugan Mariraj - Data collection and drafting of manuscript, Rajendran Kalidoss, Machampalayam Arumugam Deepa - editing of the manuscript, All Authors revised and approved the final article.

\section{CONFLICT OF INTEREST}

The authors have no conflict of interest.

\section{FUNDING AGENCIES}

The authors would like to acknowledge Indian Council of Medical Research (ICMR), New Delhi for financial support to carry out the study. (58/18/2015-TFV/BMS dated:23.02.2018).

\section{REFERENCES}

1. Jha BN, Shrestha M, Pandey DP, Bhattarai T, Bhattarai HD, Paudel B. Investigation of antioxidant, antimicrobial and toxicity activities of lichens from high altitude regions of Nepal. BMC Complement Altern Med 2017; 17:282.

2. Rodriguez CM, Bennett JP, Johnson CJ. Lichens: Unexpected antiprion agents? Prion 2012;6:11-6.

3. Shukla V, Joshi GP, Rawat MS. Lichens as a potential natural source of bioactive compounds: A review. Phytochem Rev 2010;9:303-14.

4. Zambare VP, Christopher LP. Biopharmaceutical potential of lichens. Pharm Biol 2012;50:778-98.

5. Crawford SD. Lichens used in traditional medicine. In: Ranković B, editor. Lichen Secondary Metabolites: Bioactive Properties and Pharmaceutical Potential. Cham: Springer International Publishing; 2019. p. 31-97.

6. Ismail HF, Hashim Z, Soon WT, Rahman NS, Zainudin AN, Majid FA. Comparative study of herbal plants on the phenolic and flavonoid content, antioxidant activities and toxicity on cells and zebrafish embryo. J Tradit Complement Med 2017;7:452-65.

7. Bencan Z, Sledge D, Levin ED. Buspirone, chlordiazepoxide and diazepam effects in a zebrafish model of anxiety. Pharmacol Biochem Behav 2009;94:75-80.

8. Benneh CK, Biney RP, Mante PK, Tandoh A, Adongo DW, Woode E. Maerua angolensis stem bark extract reverses anxiety and related behaviours in zebrafish-Involvement of GABAergic and 5-HT systems. J Ethnopharmacol 2017;207:129-45.

9. Poornima S, Nagarjun N, Ponmurugan P, Gnanamangai BM, Narasimman S. Toxicity and anti-inflammatory study of Parmotrema austrosinense extract against oxozalone induced intestinal inflammation in zebrafish (Danio rerio) model. Biocatal Agric Biotechnol 2019;21:101278.

10. Sztanke M, Rzymowska J, Sztanke K. Anticancer active trifluoromethylated fused triazinones are safe for early-life stages of zebrafish (Danio rerio) and reveal a proapoptotic action. J Enzyme Inhib Med Chem 2021;36:336-44.

11. Fernandes H, Peres H, Carvalho AP. Dietary protein requirement during juvenile growth of zebrafish (Danio rerio). Zebrafish 2016;13:548-55.

12. Upreti DK, Divakar PK, Nayaka S. Notes on species of the lichen genus Phyllopsora in India. Bibl Lichenol 2002;86:185-91.

13. Honda NK, Pavan FR, Coelho RG, de Andrade Leite SR, Micheletti AC, Lopes TI, et al. Antimycobacterial activity of lichen substances. Phytomedicine 2010;17:328-32.

14. Tiwari P, Rai H, Upreti DK, Trivedi S, Shukla P. Antifungal activity of a common Himalayan foliose lichen Parmotrema tinctorum (Despr. ex Nyl.) Hale. Nat Sci 2011;9:167-71.

15. Anjali DB, Mohabe S, Reddy AM, Nayaka S. Antimicrobial activities of 2-Propanol crude extract from lichen Parmotrema tinctorum (Despr. ex. Nyl.) Hale, collected from Eastern Ghats, India. Curr Res Environ Appl Mycol 2015;5:160-8.

16. Vivek MN, Yashoda K, Manasa M, Prashith KTR. Antibacterial activity of three Parmotrema species from Western Ghats of Karnataka against clinical isolates of Burn and Dental caries. Sci Technol Arts Res J 2014;3:132-5.

17. Poornima S, Ponmurugan P, Gnanamangai BM, Nagarjun N, Ayyappadasan G. Evaluation of antimicrobial, antioxidant and anticancer activities of few macrolichens collected from Eastern Ghats of Tamil Nadu, India. Int Res J Pharm 2017;8:39-43.

18. Ganesan A, Thangapandian M, Ponnusamy P, Sundararaj JP, Nayaka S. Antioxidant and antibacterial activity of parmeliod lichens from Shevaroy hills of Eastern Ghats, India. Int J Pharm Tech Res 2015;8:13-23.

19. Ponmurugan P, Ayyappadasan G, Verma RS, Nayaka S. Survey, distribution pattern and elemental composition of lichens in Yercaud hills of Eastern Ghats in Southern India. J Environ Biol 2016;37:407.

20. Awasthi DD. A Compendium of the Macrolichens from India. Nepal, Sri Lanka: Bishen Singh Mahendra Pal Sin; 2007.

21. Orange A, James PW, White FJ. Microchemical Methods for the Identification of Lichens. London: Microchem Methods Identif Lichens 2001.

22. Rajendran K, Poornima S, Ponnusamy P. Antimicrobial and antiproliferative activities of depside compound isolated from the mycobiont culture of Parmotrema austrosinense (Zahlbr.) Hale. J Pure Appl Microbiol 2020;14:2525-41.

23. Culberson CF. Improved conditions and new data for identification of lichen products by standardized thin-layer chromatographic method. J Chromatogr A 1972;72:113-25.

24. OECD. Test No. 203: Fish, Acute Toxicity Test. Paris: OECD Publishing; 1992. 
25. Pittman J, Hylton A. Behavioral, endocrine, and neuronal alterations in zebrafish (Danio rerio) following sub-chronic coadministration of fluoxetine and ketamine. Pharmacol Biochem Behav 2015;139:158-62.

26. Cachat J, Stewart A, Grossman L, Gaikwad S, Kadri F, Chung KM, et al. Measuring behavioral and endocrine responses to novelty stress in adult zebrafish. Nat Protoc 2010;5:1786-99.

27. Krishnaraj C, Harper SL, Yun SI. In vivo toxicological assessment of biologically synthesized silver nanoparticles in adult Zebrafish (Danio rerio). J Hazard Mater 2016;301:480-91

28. Lee PY, Costumbrado J, Hsu CY, Kim YH. Agarose gel electrophoresis for the separation of DNA fragments. JoVE J Vis Exp 2012;2012:e3923.

29. Sambrook J, Russell DW. Alkaline Agarose Gel Electrophoresis. CSH Protocols; 2006.

30. Wang D, Yang L, Wang J, Hu G, Liu Z, Yan D, et al. Behavioral and physiological effects of acute and chronic kava exposure in adult zebrafish. Neurotoxicol Teratol 2020;79:106881.

31. Collier AD, Kalueff AV, Echevarria DJ. Zebrafish models of anxietylike behaviors. In: Kalueff AV, editor. Rights Wrongs Zebrafish Behavioral Phenotyping of Zebrafish. Cham: Springer International Publishing; 2017. p. 45-72.

32. Maximino C, de Brito TM, da Silva Batista AW, Herculano AM,
Morato S, Gouveia A. Measuring anxiety in zebrafish: A critical review. Behav Brain Res 2010;214:157-71.

33. Dutta HM. A composite approach for evaluation of the effects of pesticides on fish. In: Fish Morphology. New Horizons, Leban NH. Science Publications; 1996. p. 249-69.

34. Harvie EA, Huttenlocher A. Neutrophils in host defense: New insights from zebrafish. J Leukoc Biol 2015;98:523-37.

35. Matthias KA, Roche AM, Standish AJ, Shchepetov M, Weiser JN. Neutrophil-toxin interactions promote antigen delivery and mucosal clearance of Streptococcus pneumoniae. J Immunol 2008;180:6246-54.

36. Woodfin A, Voisin MB, Beyrau M, Colom B, Caille D, Diapouli FM, et al. The junctional adhesion molecule JAM-C regulates polarized transendothelial migration of neutrophils in vivo. Nat Immunol 2011;12:761-9.

37. Johnston IA, Bower NI, Macqueen DJ. Growth and the regulation of myotomal muscle mass in teleost fish. J Exp Biol 2011;214:1617-28.

38. Hong JM, Kim JE, Min SK, Kim KH, Han SJ, Yim JH, et al. Antiinflammatory effects of antarctic lichen Umbilicaria antarctica methanol extract in lipopolysaccharide-stimulated RAW 264.7 macrophage cells and zebrafish model. BioMed Res Int 2021;2021:8812090. 